\title{
ЗАСТОСУВАННЯ ВІДКРИТОГО ПРОГРАМНОГО КОМПЛЕКСУ ДЛЯ ОБРОБКИ МЕДИЧНИХ ЗОБРАЖЕНЬ MЕVISLAВ ПРИ ВИВЧЕННІ КУРСУ «МЕДИЧНА ІНФОРМАТИКА»
}

\author{
Н. О. Кравець, А. В. Семенець, А. С. Сверстюк \\ ДВНЗ «Тернопільський державний медичний університет \\ імені І. Я. Горбачевського МОЗ України»
}

\begin{abstract}
Показано основні можливості програмного комплексу MeVisLab у галузі обробки медичних зображень. Описано його структуру та інтерфейс користувача. Наведено методику застосування програмного комплексу MeVisLab при вивченні окремих розділів курсу «Медична інформатика». Продемонстровано підходи до реалізації алгоритмів розпізнавання окремих елементів зображення.
\end{abstract}

Ключові слова: обробка медичних зображень, програмний комплекс MeVisLab, алгоритми розпізнавання зображення, сегментація медичних зображень.

\section{ПРИМЕНЕНИЕ ОТКРЫТОГО ПРОГРАММНОГО КОМПЛЕКСА ДЛЯ ОБРАБОТКИ МЕДИЦИНСКИХ ИЗОБРАЖЕНИЙ MЕVISLAВ ПРИ ИЗУЧЕНИИ КУРСА «МЕДИЦИНСКАЯ ИНФОРМАТИКА»}

\author{
Н. О. Кравець, А. В. Семенець, А. С. Сверстюк \\ ГВУЗ «Тернопольский государственный медицинский университет \\ имени И. Я. Горбачевского МЗ Украины»
}

\begin{abstract}
Показаны основные возможности программного комплекса MeVisLab в области обработки медицинских изображений. Описана его структура и интерфейс пользователя. Приведена методика применения программного комплекса MeVisLab при изучении отдельных разделов курса «Медицинская информатика». Продемонстрировано подходы к реализации алгоритмов распознавания отдельных элементов изображения.
\end{abstract}

Ключевые слова: обработка медицинских изображений, программный комплекс MeVisLab, алгоритмы распознавания изображений, сегментация медицинских изображений.

\section{ON APPLICATION OF THE OPEN SOURCE MEDICAL IMAGES PROCESSING SOFTWARE MEVISLAB IN THE STYDING OF THE MEDICAL INFORMATICS}

N. O. Kravets, A. V. Semenets, A. S. Sverstyuk

SHEI «Ternopil State Medical University by I. Ya. Gorbachevsky of MPH of Ukraine»

\begin{abstract}
The main capabilities of the MeVisLab image analysis suite to the medical images processing are shown. The application software package structure and the user interface are described. The methodology of the MeVisLab software package usage to the studying of the corresponded topics of the Medical Informatics course is presented. An approach of the implementation of the image elements recognition algorithm is demonstrated.
\end{abstract}

\footnotetext{
Key words: medical image processing, MeVisLab envirenment, image recognition algorithms, segmentation of medical images.

Вступ. На сьогоднішній день обробка зображень $\epsilon$ важливим напрямком застосування сучасної обчислювальної техніки. Відомі такі завдання обробки зображень як фільтрація і відновлення зо-

інформації. Крім класичної задачі розпізнавання фігур заданої форми на зображенні, постають нові задачі - розпізнавання ліній і кутів на зображенні, розпізнавання його краю.
} бражень, сегментація зображень, засоби стиснення 
Обробка зображень є багатоплановим завданням. Сюди включають рішення задач: фільтрації шумів, геометричної корекції, характеристичної корекції, посилення локальних контрастів і різкості, відновлення зображень та ін.

Для вирішення всіх перерахованих вище завдань в останні роки активно використовують відповідні прикладні засоби. Існує ряд програмних продуктів, які дозволяють підняти проблему обробки медичних зображень на якісно новий рівень [1-4].

Основна частина. Одним із таких програмних продуктів є MeVisLab - потужний, гнучкий і простий в управлінні засіб для обробки зображень i візуалізації з акцентом на медицину. Його переваги включають:

- можливість роботи 3 великими шестивимірними зображеннями ( $x, y, z$, колір, час, параметр користувача);

- модульний принцип розробки алгоритмів;

- ефективні прийоми візуального проектування та моделювання;

- високу продуктивність.

Крім загальних алгоритмів обробки зображень i графічного підходу до програмування, MeVisLab включає в себе передові медичні модулі візуалізації для сегментації, реєстрації, кількісних морфологічних оцінок і функціонального аналізу.

MeVisLab використовує ряд відомих сторонніх бібліотек і технологій, наприклад Framework, набip інструментів Open Inventor, скриптову мову Python, графічну бібліотеку OpenGL, а також модулі на базі Insight ToolKit (ITK) i Visualization ToolKit (VTK).

B MeVisLab завдання 3 обробки зображень peaлізуються на трьох рівнях:

1. Візуальний рівень: реалізація підходу візуального проектування не вимагає попередніх знань в галузі програмування, проте забезпечує індивідуальну обробку зображень, ефективну взаємодію модулів, які можуть бути об'єднані в комплекс по візуалізації зображень.

2. Сценарії: створення макросів, модулів і додатків з використанням засобів мов програмування Python або JavaScript. У сценарії можуть бути додані компоненти для реалізації динамічних функцій обробки та аналізу зображень і налаштування користувацького інтерфейсу.

3. Програмування модулів: нові алгоритми можуть бути легко інтегровані з використанням модульної, незалежної від платформи, С++ бібліотеки.
Крім того, абстрактні ієрархічні мережі MeVisLab Definition Language (MDL) дозволяють спроектувати ефективний графічний користувальницький інтерфейс, приховуючи його складність від кінцевого користувача.

3 точки зору розробки додатків це виглядає наступним чином:

1. Здійснюється підключення існуючих модулів або розробка нових.

2. Збирається користувальницький графічний інтерфейс (GUI).

3. Записуються макроси для складних функцій.

4. Розробляються скрипти для управління мережами, графічними інтерфейсами і макросами.

5. Виконується збірка користувацького інсталяційного пакета (за наявності спеціальної ліцензії ADK).

У рамках парадигми візуального проектування алгоритм обробки зображення в MeVisLab представлений у вигляді мережі модулів, з'єднаних різними способами. Мінімальний комплекс обробки чи/та аналізу зображень складається 3 модуля джерела зображення, модуля, що реалізує алгоритм обробки зображень і модуля перегляду результату (рис. 1).

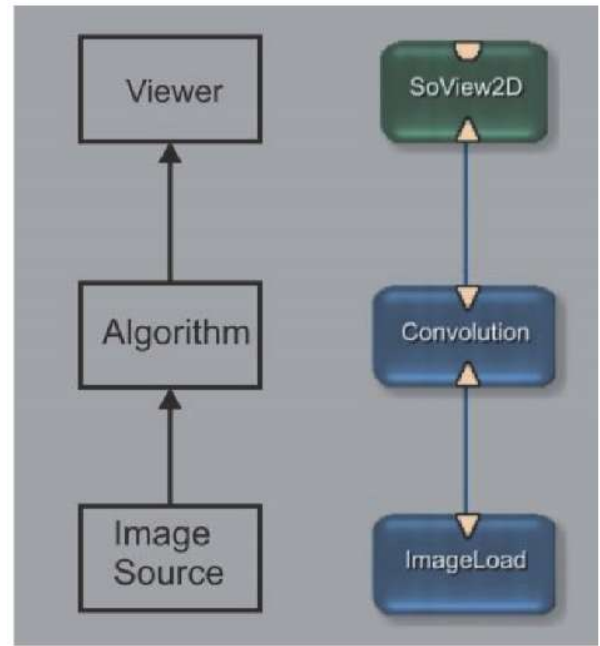

Puc. 1. Структура мінімальної мережі алгоритму візуалізації в MeVisLab.

Модулі. В рамках концепції MeVisLab, базові сутності, 3 якими працює користувач - це графічне представлення модулів 3 їх специфічними функціями для обробки зображень, візуалізації та взаємодії. Три основних типи модулів відрізняються кольором (синій, зелений, коричневий). Відмітки червоним вказують на наявність помилок у модулі.

Зв'язки. Більшість модулів включають роз'єми, що є входами (внизу) і виходами (вгорі). Визна- 


\section{МЕДИЧНА ІНФОРМАТИКА TA IHЖЕНЕРІЯ}

чено три типи роз ємів за призначенням, що відрізняються за формою (трикутник, півколо, квадрат). При підключенні цих роз'ємів дані зображення або інша інформація транслюються 3 одного модуля в інший або кілька інших. Теоретично, всі модулі можуть бути підключені до інших модулів, сумісних за параметрами з'єднання.

Поля. Поля визначають інтерфейс модуля i $\epsilon$ основою для різних типів роз'ємів:

- поля для вводу / виводу можуть бути зображеннями, вузлами, об'єктами;

- параметри поля можуть мати числовий, стрічковий та логічний тип даних;

- допустимими є типи даних у вигляді векторів та тригерів.

Параметри полів можуть бути змінені в ході роботи.

Мережі. Зв'язки між модулями (так звані мережі) призначені для виконання складних завдань 3 обробки даних. Такі мережі складаються 3 набору стандартних модулів, утворюючи макромодулі. Макромодулі можуть ефективно працювати 3 підмережами. Мережі можна редагувати і зберігати як файли з розширенням *.mlab.

\section{Інтерфейси управління користувача}

MeVisLab використовує графічний інтерфейс користувача і надає інтерфейс розробки сценаріїв. Кожен модуль пов'язаний з автоматичною панел- лю, на якій перераховані всі доступні параметри, поля та методи даного модуля. При необхідності для користувача панелі можуть бути змінені - зроблені більш зручними для користувачів, наприклад, згруповані, оснащені додатковими полями.

Компоненти користувацького інтерфейсу:

- контроль вхідних даних користувача, можливість редагування тексту, спливаючі меню, радіокнопки, прапорці і кнопки запуску;

- компонування елементів управління: як горизонтальна, так і вертикальна;

- складні й динамічні елементи управління, різноманітний дизайн.

Програма MeVisLab дозволяє працювати 3 двота тривимірними зображеннями, отриманими за допомогою різних методів та джерел.

Студентам запропоновано задачі, які демонструють діапазон можливостей MeVisLab при роботі 3 різними видами зображень, приклади яких наведено далі.

Завдання 1. Вивчення базових функціональних можливостей MeVisLab

Студенти ознайомлюються 3 графічним інтерфейсом MeVisLab. Показано методи роботи 3 файлами додатку та кількома мережами на різних вкладках робочої області. Здійснюється пошук та додавання модулів до існуючої мережі (рис. 2).

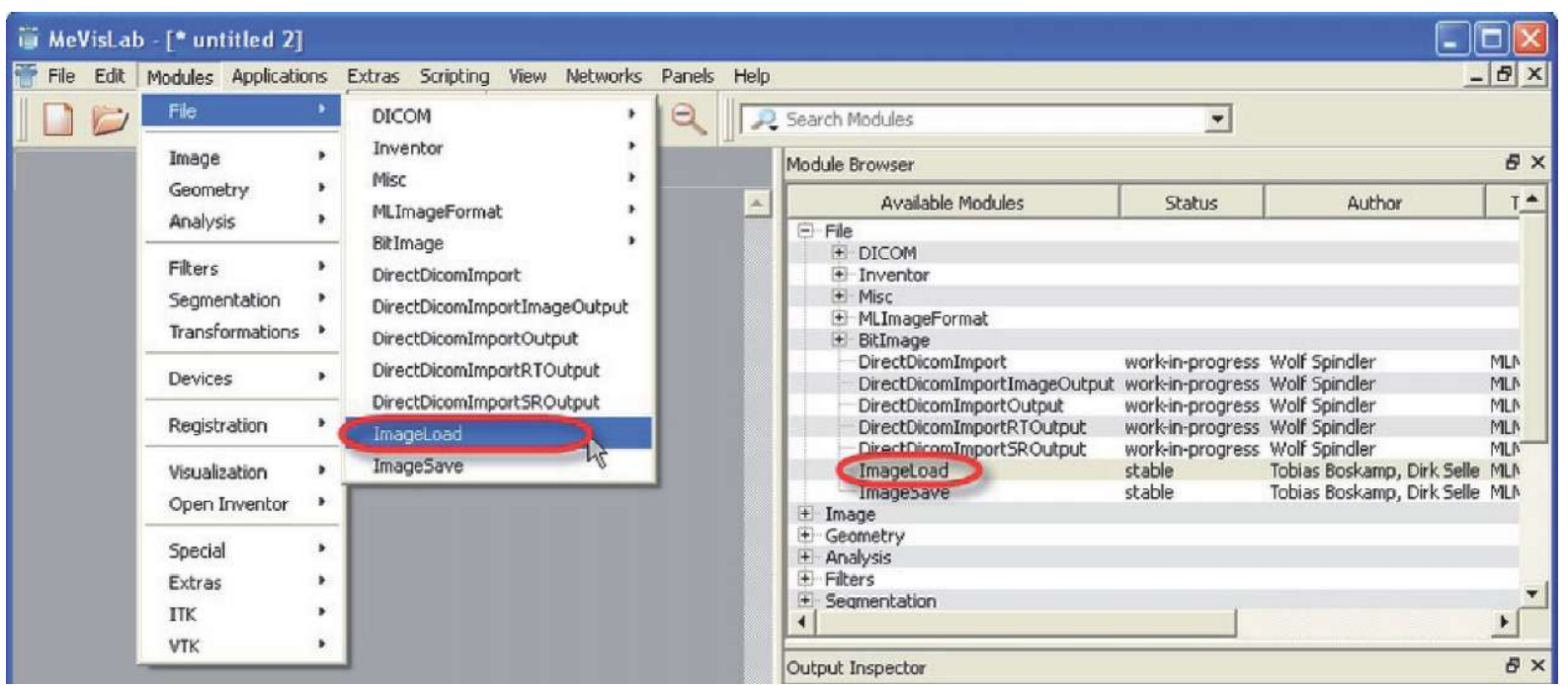

Puc. 2. Два варіанти завантаження модуля в MeVisLab.

Показано процедуру використання модуля ImageLoad:

- відкрити панелі Views Output Inspector i Module Inspector та ImageLoad модуля;

- клацнути лівою кнопкою «миші» (КЛМ) вихідний роз'єм модуля ImageLoad (рис. 3) для ви- ведення зображення у вікні Output Inspector (показує вихід будь-якого роз'єму в технологічному ланцюжку);

- КЛМ вікно Output Inspector для активації та прокрутити зрізи (за допомогою коліщатка миші або клавіш зі стрілками). 


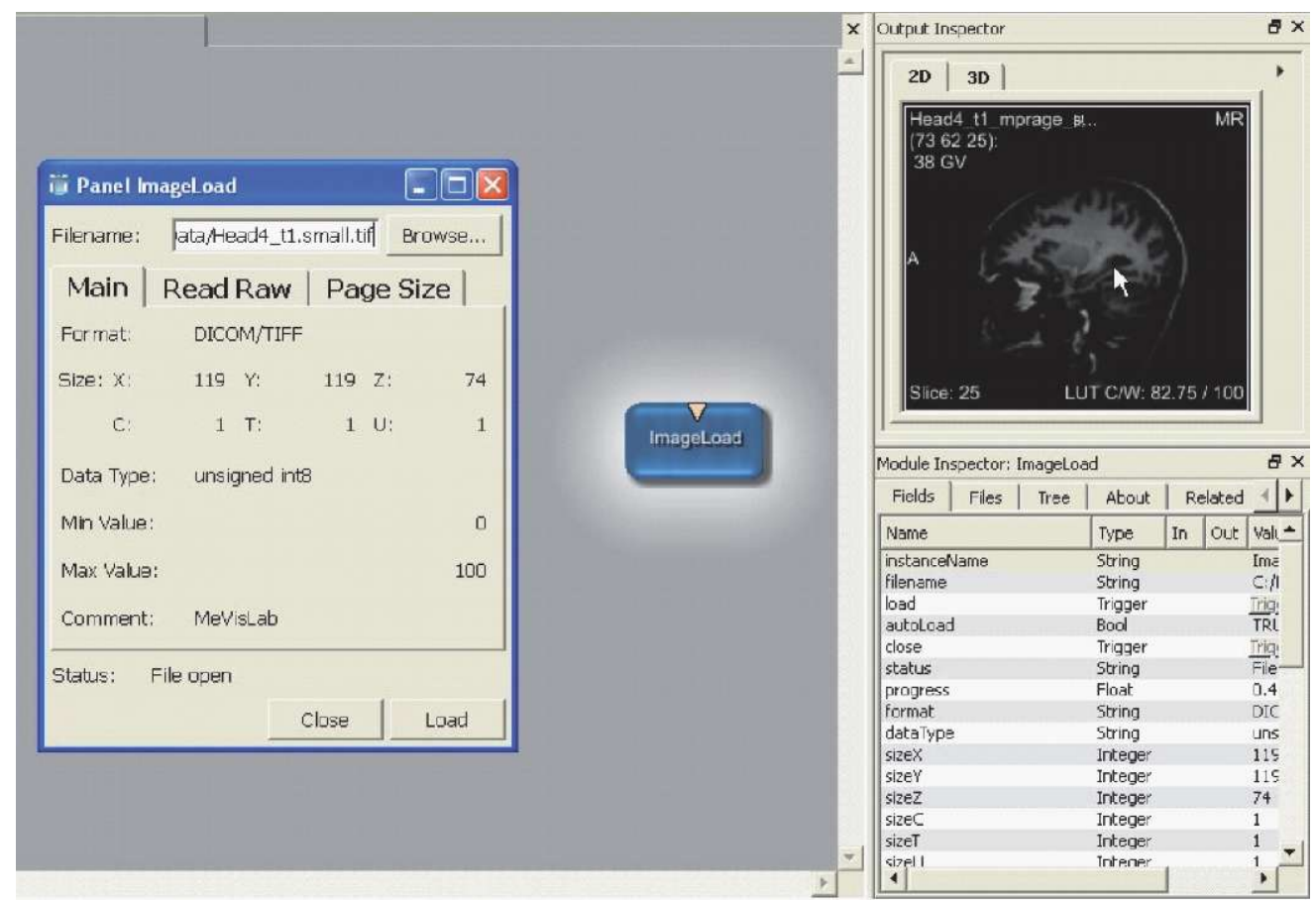

Puc. 3. Робота з модулем ImageLoad.

Після встановлення налаштувань можна перегорнути всі наявні (72 для даного прикладу) зрізи томографічного зображення голови.

Для отримання додаткової інформації про зображення, на панелі Output Inspector потрібно натиснути кнопку •. Властивості зображення містять, зокрема, наступну інформацію:

- характеристики зображення х, $y, z, c, t, n$;

- розмір сторінки;
- тип даних і діапазон;

- розмір вокселя в міліметрах.

Вкладки 2D та 3D відображають плоске та синтезоване тривимірне зображення (рис. 4 та рис. 5).

Вказані 2D- i 3D-представлення не залежать один від одного. 3D- зображення можна повертати. Для орієнтації служить маленький куб (або інша фігура) в одному з кутів перегляду (позначення: $A$ - спереду, $P$ - ззаду, $R$ - праворуч, $L$ - зліва, $H$ зверху; $F-$ знизу).

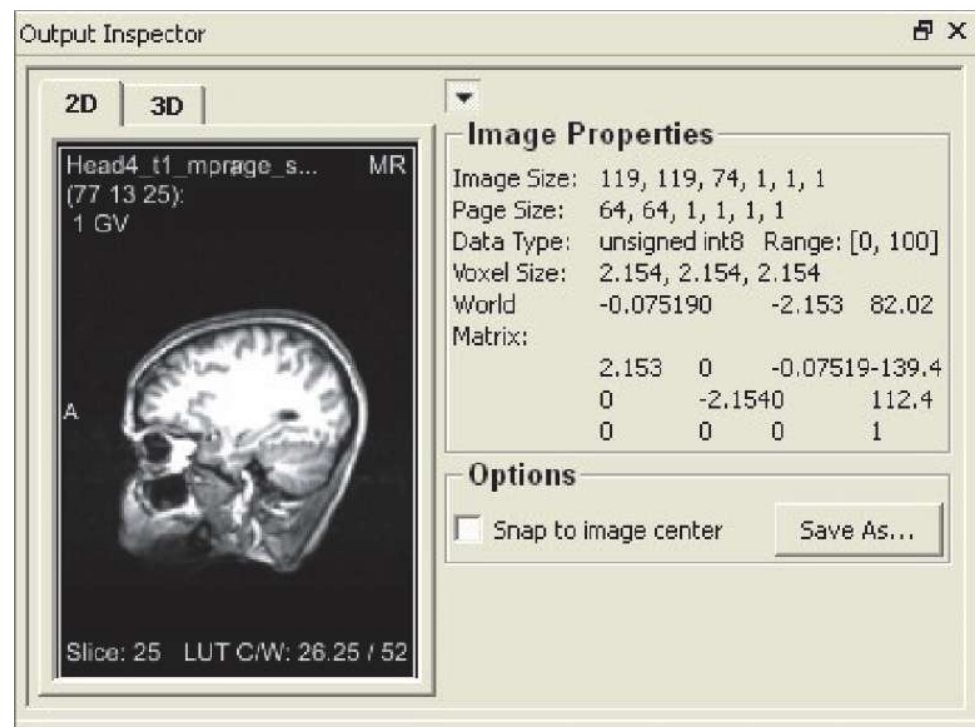

Рuc. 4. Панель Output Inspector - Вкладка 2D.

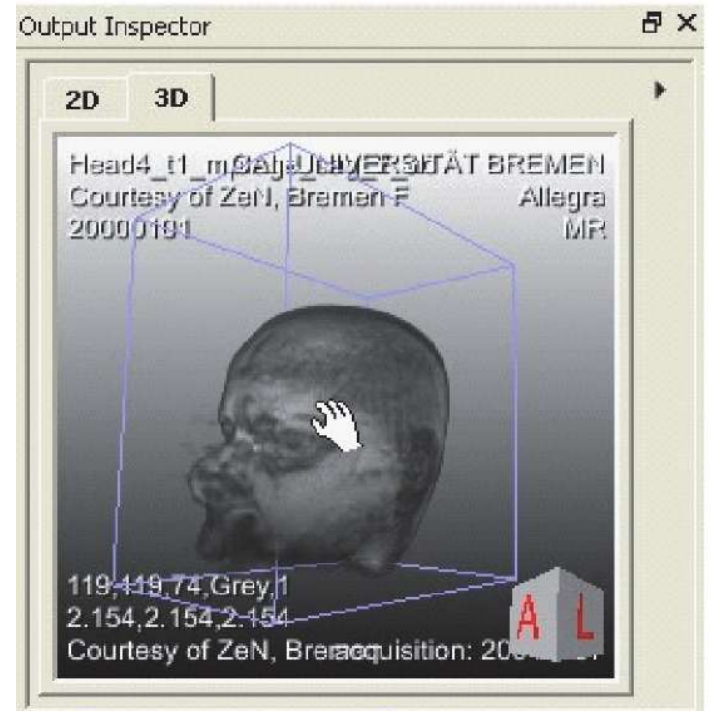

Puc. 5. Панель Output Inspector - Вкладка 3D. 


\section{МЕДИЧНА ІНФОРМАТИКА ТА ІНЖЕНЕРІЯ}

Інформація, наведена у властивостях Output Inspector, може відображатися також поряд 3 роз'ємом модуля. Для цього потрібно встановити прапорець у вікні Preferences (команда меню Edit - Preferences).

Візуалізація результатів обробки зображення мережею MeVisLab здійснюється двома спеціалізованими модулями, а саме View2D i View3D. View2D (рис. 6) найчастіше використовується для вивчення результатів обробки зображень в ході роботи. Панель View2D надає користувачу велику кількість функцій, наприклад масштабування, огляд, анотації, кінорежим і багато іншого.

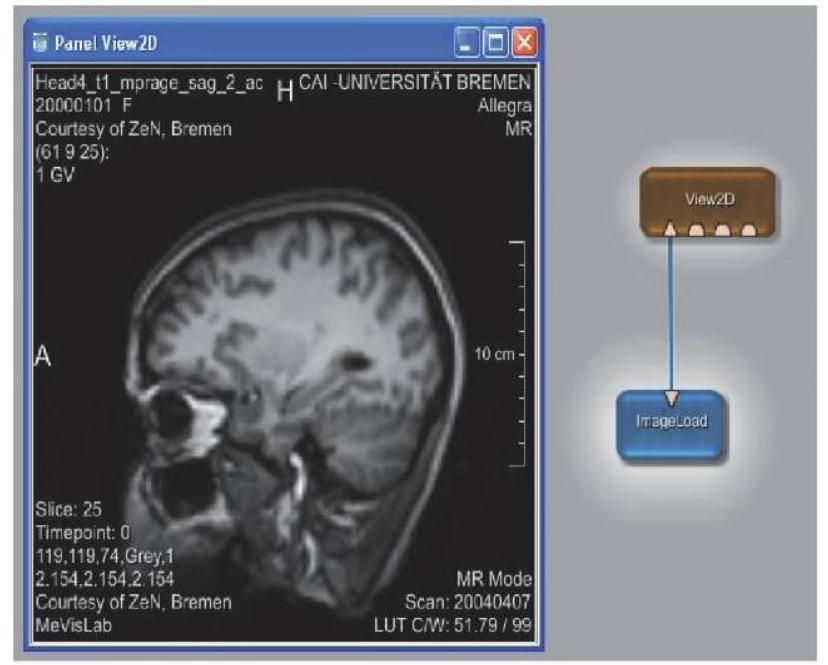

Puc. 6. Зображення на панелі View2D.
Додавання модуля View3D до мережі (рис. 7) дозволяє отримати 3D-зображення наведеного прикладу. Панель модуля View3D (рис. 8) включає велику кількість опцій щодо налаштування параметрів перегляду. Наявні засоби генерації перерізів та зрізів зображення.

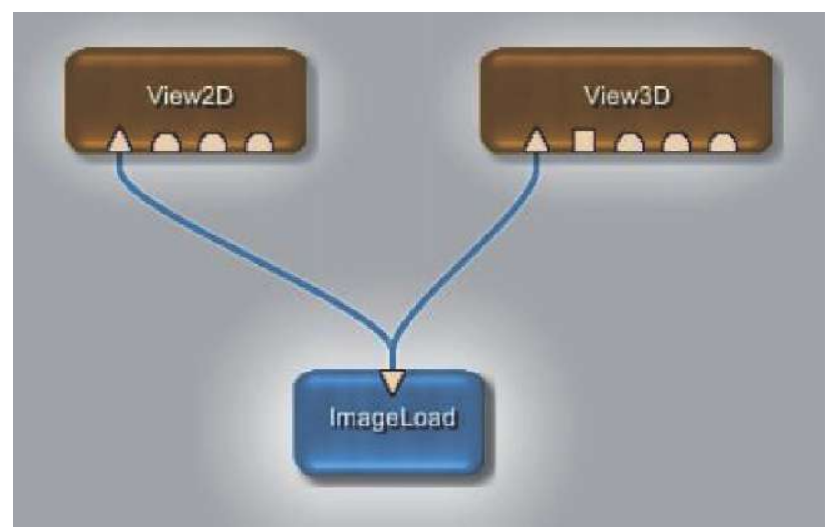

Рис. 7. Підключення вихідного роз'єму до кількох модулів візуалізації.

\section{Завдання 2. Вивчення процесу сегментаціі зображення на прикладі побудови контур- фільтра}

Студенти ознайомлюються 3 загальною методологією обробки медичних зображень за допомогою MeVisLab. Показано процес побудови контурфільтра, як приклад вирішення задачі сегментації медичного зображення. Наведено покрокову

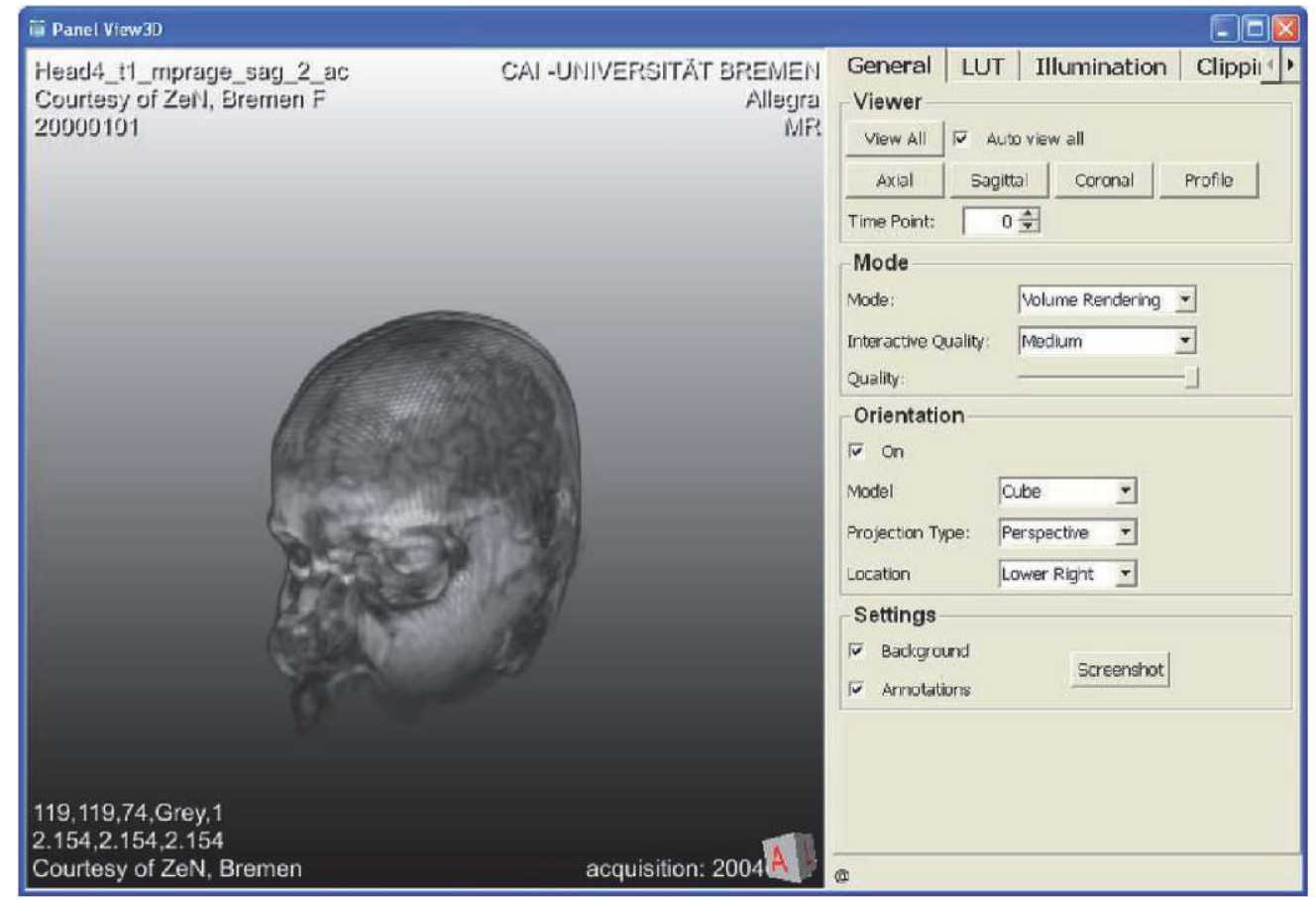

Рuc. 8. Панель модуля View3D і її налаштування. 
інструкцію побудови необхідної мережі модулів MeVisLab. Наочність результату обробки підкреслюється створенням синхронізованого переглядача зображення - 3 фільтрацією і без неї.

Найпростіша реалізація контур-фільтра включає такі кроки обробки вхідного зображення:

1. Завантаження вхідного зображення input image $a$.

2. Згладжування вхідного зображення: Average [image a] $\rightarrow$ image $b$.

3. Обробка згладженого зображення за допомогою морфологічних операцій: Dilate [image b] $->$ image $c$.

4. Віднімання згладженого зображення з розтягуванням згладженої картинки: Subtract [image $c$, image b] $\rightarrow>$ image $d$.

5. Вивід вихідного зображення Output Image D.

Для даного конвеєра обробки застосовуються наступні модулі MeVisLab:
- модуль усереднення: Convolution;

- модуль морфології Morphology;

- один 3 інструментів арифметичної обробки: Arithmetic2.

Призначення модулів арифметичної обробки зображень наступне:

- Arithmetic0 застосовується для арифметичних операцій на скалярних або 3D-векторах;

- Arithmeticl виконує арифметичні операції на одному збраженні;

- Arithmetic2 застосовується для арифметичних операцій над двома зображеннями одночасно.

Типовий вигляд мережі MeVisLab, що є базовою реалізацією контур-фільтра, та параметри налаштувань окремих модулів, показано на рисунку 9. На рисунку 10 продемонстровано результати роботи контур-фільтра, шляхом візуалізації фільтрованого та нефільтрованого зображення 3 єдиного джерела.

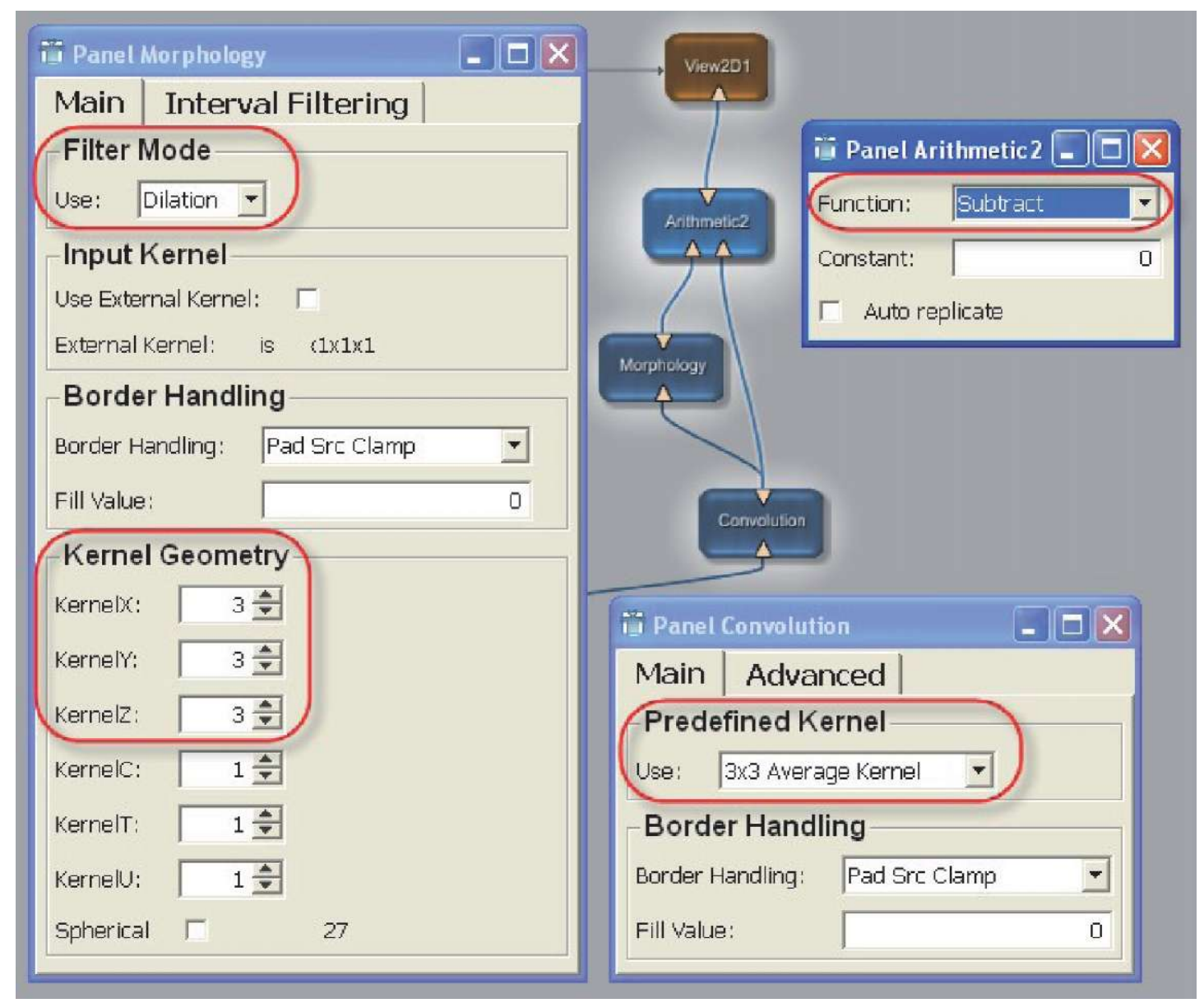

Puc. 9. Загальний вигляд та налаштування модулів мережі контур-фільтра.

Синхронізація модулів. Крім передачі даних між модулями за допомогою роз'ємів можна підключити модуль за допомогою з'єднання. Значення пов'язаних полів будуть синхронізовані. При цьому суттєвими є такі моменти: 


\section{МЕДИЧНА ІНФОРМАТИКА TA ІНЖЕНЕРІЯ}

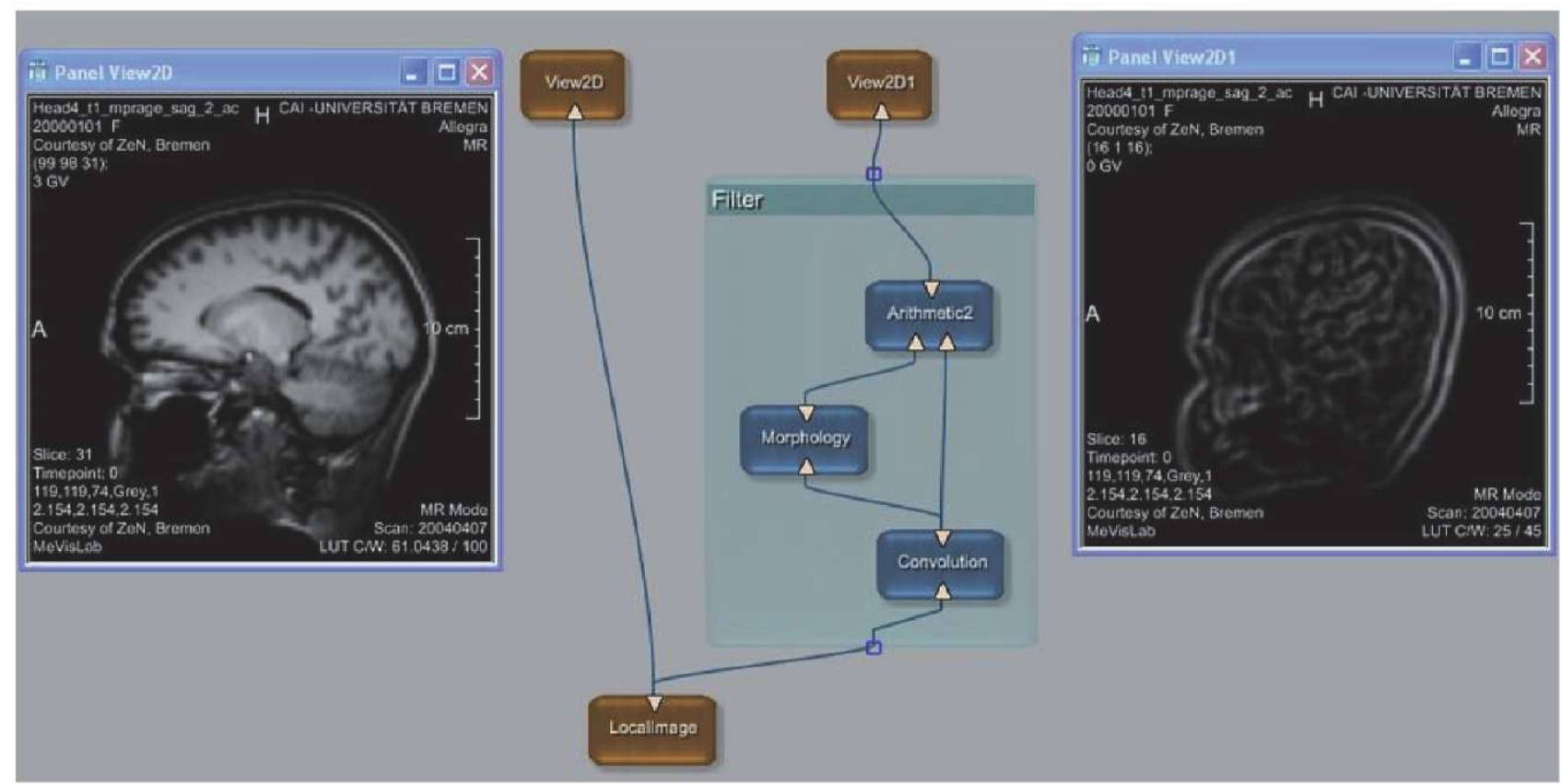

Puc. 10. Результати обробки томографічого зображення голови за допомогою контур-фільтра.

1. Поля можуть бути підключені до довільного числа інших областей в якості джерела, але тільки один раз в якості точки призначення.

2. Зв'язки між полями можуть бути односпрямованими або двонаправленими. В однонаправленому зміни в полі $A$ відбиваються в поле $B$, але зміни в полі $B$ не впливають на поле $A$. В двонаправленому зміни в полі $A$ відбиваються в поле $B$, і зміни в полі $B$ відображаються в поле $A$. Однак MeVisLab перешкоджає створенню нескінченних циклів.

3. Зазвичай зв'язані поля повинні бути одного типу.

4. Параметри з'єднання можуть бути встановлені як між полями в одному модулі, так і між полями різних модулів.

5. Параметри з'єднання встановлюються шляхом перетягування полів на мітки панелей. у даному прикладі для встановлення двонаправленого зв'язку слід виконати наступні кроки (рис. 11):

1. У контекстному меню кожного View2D-модуля виберіть команду Show Window - Automatic Panel. Поле, яке контролює початковий номер зрізу в View2D-модулі, називається startSlice.

2. На панелі View2D виберіть мітку поля startSlice і потягніть невидимий зв'язок на мітку поля startSlice панелі View2D1. Зв'язок буде зображено як тонку сіру стрілку від одного модуля до іншого.

3. Повторіть процес в зворотному напрямку, перетягуючи поле startSlice 3 View2D1 на панель View2D. Стрілка зв'язку стане двонаправленою.

Загальний вигляд даної мережі контур-фільтр 3 синхронізованим переглядом показано на рисунку 12.

\begin{tabular}{|c|c|c|c|c|c|c|c|c|c|c|c|c|c|}
\hline \multicolumn{5}{|l|}{ 1] Panel View2D } & $=\square$ & $\mathrm{x}$ & \multicolumn{5}{|l|}{ if Panel View2D1 } & \multicolumn{2}{|c|}{ - $\square x$} \\
\hline Parameters & Inputs & Out & puts & & & & Parameters & Inputs & Out & puts & & & \\
\hline Name & Type & In & Out & Value & & - & Name & Type & In & Out & Value & & $\triangle$ \\
\hline instanceNlame & String & & & View2 & & & instanceName & String & & & View2D1 & & \\
\hline inventor Inputon & Bool & & & EHESE & & & 1.mentrarinauton & Bool & & & FALSE & & \\
\hline view $2 \mathrm{DEx}$ tensionsor & Bool & & & TRUE & & & view2DExtensionso & neal & & & TRUE & & \\
\hline startSlice & Integer & $F$ & $\rightarrow$ & 31 & & & startSlice & Intege & & $\rightarrow$ & 31 & & \\
\hline numslices & Integer & & & 1 & & & numslices & Intege & & & 1 & & \\
\hline numxSlices & Integer & & & 1 & & & numasices & Invege & & & 1 & & \\
\hline
\end{tabular}

Puc. 11. Створення додаткового зв'язку між модулями. 


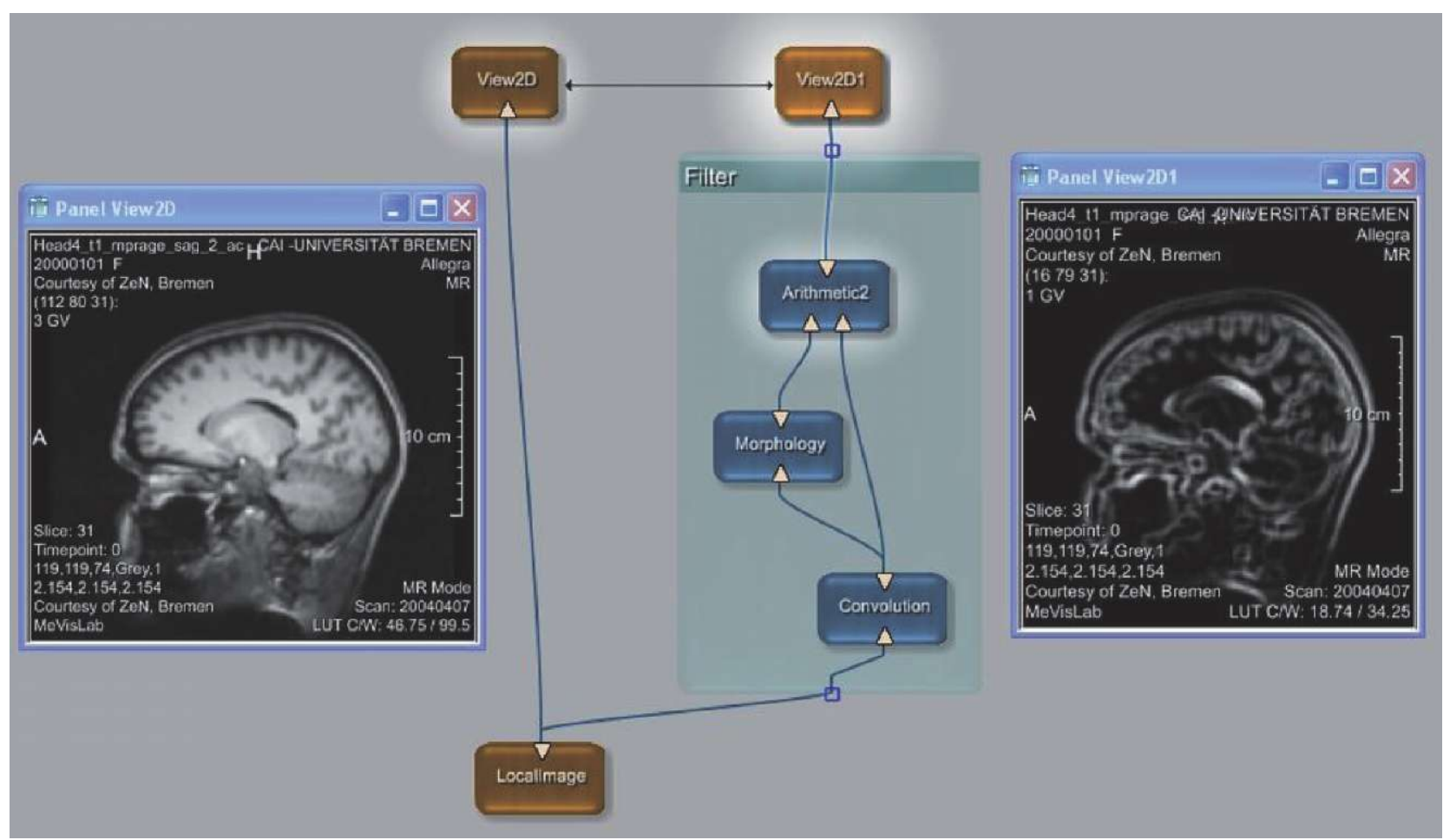

Puc. 12. Синхронізований перегляд медичного зображення.

Висновки. Впровадження сучасних програмних засобів $\epsilon$ необхідною умовою забезпечення якості надання медичної допомоги. Застосування спеціалізованих програмних продуктів, зокрема MeVisLab, дає можливість підвищити точність та якість діагностичних рішень при роботі з медичними зображеннями. Велике значення має вивчення можливостей MeVisLab та іншого програмного

\section{Література}

1. Кравець Н. О. Застосування відкритого програмного комплексу ImageJ в курсі вивчення медичної інформатики / Н. О. Кравець, А. В. Семенець, Н. Я. Климук // Медична освіта. - 2014. - № 4. - С. 63-68.

2. Сверстюк А. С. Підхід до застосування сервісу WOLFRAMALFA для математичного моделювання в медицині і фармації на прикладі розв'язання задач фармокінетики / Н. О. Кравець, А. С. Сверстюк, Д. В. Вакуленко // Медична інформатика. - 2015. - № 1. - C. 47-51. забезпечення для візуалізації, обробки та аналізу медичних зображень в рамках курсу «Медична інформатика». Таким чином забезпечується високий рівень якісної підготовки майбутнього лікаря - фахівця. Формуються навики застосування сучасних IT-технологій в його майбутній щоденній професійній діяльності.

3. Прокопченко О. Є. Огляд окремих математичних методів та алгоритмів опрацювання медичних зображень на прикладі технології Вольфрам математика / О. Є. Прокопченко // Медична інформатика. - 2015. - № 3.- C. 66-68.

4. Medical Image Analysis: A visual approach / F. Ritter, T. Boskamp, A. Homeyer [et al.] // IEEE Pulse. - 2011. № 2 (6). - C. 60-70 . 